\title{
Selim İleri’nin Hepsi Alev romanında bilinç akışı tekniğine dayalı dil ve anlatım özellikleri'
}

\section{Hasene AYDIN2}

\begin{abstract}
APA: Aydın, H. (2019). Selim İleri’nin Hepsi Alev romanında bilinç akışı tekniğine dayalı dil ve anlatım özellikleri. RumeliDE Dil ve Edebiyat Araştırmaları Dergisi, (Ö6), 106-122. DOI: 10.2900o/rumelide.648459.
\end{abstract}

\section{$\ddot{\mathbf{O} z}$}

Bilinç akışı tekniği, edebiyatta modern anlatım yöntemlerinden biri olarak kabul edilir. Kahramanların iç dünyalarında olup bitenleri, düşünceleri, duyguları anlatmaya yarayan bu yöntemle kahraman öne çıkarılır. Okurla baş başa kalan kahraman, aklından geçenleri kendi ağzından aktarır. Türk edebiyatında bilinç akışı tekniğini kullanan yazarlardan biri de Selim İleri'dir ve bu çalışmanın konusu olan Hepsi Alev adlı romanında da bu yöntemden yararlanır. Araştırmalarda, bilinç akışı tekniği kullanılırken çoğu zaman dil bilgisi kurallarına uyulmadığı belirtilir. Ancak hangi kurallara uyulmadığı ya da nasıl bir anlatımın tercih edildiği ayrıntılarla ele alınmaz. Bir dil incelemesi olan bu çalışmada, Hepsi Alev romanı örnek alınarak bilinç akışı tekniğinden kaynaklanan kullanımların dil bilgisi kuralları çerçevesinde değerlendirilmesi hedeflenmektedir. Roman, bu anlamda pek çok veri sunar. Zamanda geri gidişler, ana dönüşler, birbirinden anlamca kopuk cümlelerin art arda sıralanması, kesik cümlelerin fazlalığı, tutarlılık ilkesinden uzaklaşıldığını göstermektedir. Alışılmamış bağdaştırmalarla da sıra dışı kullanımlar yaratılmıştır. Eksiltili anlatımlarla cümle sayısının artırılması ve yüzey yapıdaki gereksiz tekrarlar, dilde en az çaba ilkesinin göz ardı edildiğinin göstergesidir. Kimi dil birimleri de bağdaşıklık kuralları gözetilmeden sıralanmıştır. Bunların dışında dil bilgisi açısından aykırılık göstermeyen bazı kullanımların da bilinç akışı tekniğine bağlı olarak tercih edildiği dikkati çeker. Kahraman, ara cümle ve ara sözlere, devrik yapılara, yorum ve çıkarım cümlelerine sıkça başvurur. Seçilen dil birimleri, kimi zaman gizli bir diyalog hissi uyandırmaktadır. Çalışma boyunca bu ve benzeri konular örneklendirilerek bilinç akışının dili ortaya konmaya çalışılmıştır.

Anahtar kelimeler: Selim İleri, Hepsi Alev, bilinç akışı, dil ve anlatım, cümle.

\section{Language and expression features based on stream of consciousness technique in Selim İleri's Hepsi Alev novel}

\begin{abstract}
The stream of consciousness technique is accepted as one of the modern methods of expression in literature. The hero is put forward with this method, which is used to express what is happening in the inner world of heroes, thoughts and feelings. The hero, who is left alone with the reader, transfers his mind from his own mouth. Selim İleri is one of the writers who use the stream of consciousness technique in Turkish literature and uses this method in his novel Hepsi Alev, which is the subject of

\footnotetext{
1 Bursa Uludă̆ Üniversitesi Bilimsel Araştırma Projeleri Biriminin desteklediği KUAP(F)-2018/15 numaralı "Uludă Üniversitesinde Çocuklarla 'Masal ve Dil' Yolculuğu-Masal Üniversitesi” adlı proje kapsamında hazırlanan bu çalışma, 26-28 Eylül 2019 tarihleri arasında Bandırma Onyedi Eylül Üniversitesi tarafından Bandırma'da düzenlenen BICOASP Uluslararası Akademik Filoloji Çalışmaları Konferansında sunulan bildirinin genişletilmiş hâlidir.

2 Ars. Gör. Dr., Bursa Uludă̆ Üniversitesi, Fen Edebiyat Fakültesi, Türk Dili ve Edebiyatı Bölümü (Bursa, Türkiye), hasenek@uludag.edu.tr, ORCID ID: oooo-0002-8478-744X [Makale kayıt tarihi: 07.10.2019-kabul tarihi: 20.11.2019;
} DOI: $10.29000 /$ rumelide.648459]
\end{abstract}




\begin{abstract}
this study. In studies, it is often stated that grammar rules are not followed when using the stream of consciousness technique. However, which rules are not followed or what kind of expression is preferred is not discussed in detail. In this study, which is a language analysis, it is aimed to evaluate the usages arising from the stream of consciousness technique within the framework of grammar rules by taking a sample of Hepsi Alev. The novel presents a lot of data in this sense. Flashbacks and turnings to the moment, sequencing of sentences which are disconnected semantically from each other, excess of elliptic clauses show that the principle of consistency has been removed. Unusual uses have been created with unaccustomed compatibilities. Increasing the number of sentences with elliptical expressions, unnecessary repetitions in the surface structure is an indication that the principle of least effort in language is ignored. Some language units are also listed without regard to the rules of cohesion. It is also noteworthy that some usages that do not contradict the grammar are preferred depending on the stream of consciousness technique. The hero often refers to parenthetical sentences, parenthetical statements, inverted structures, interpretation and inference sentences. Occasionally, the selected language units evoke a secret dialogue. Throughout the study, the language of the stream of consciousness has been tried to be put forward by exemplifying these and similar issues.
\end{abstract}

Keywords: Selim İleri, Hepsi Alev, stream of consciousness, language and expression, sentence.

\title{
Giriş
}

Bir anlatma sanatı olan edebiyat, dile dayanmakta; temel malzeme olarak dilden yararlanmaktadır. Edebî eserlerde kullanılan dil de sanatçıların, amaçlarına uygun olarak tercih ettikleri pek çok anlatım tekniğine göre biçimlenir. Bunlardan biri, sıklıkla başvurulan bilinç akışı tekniğidir.

"Bilinç akımı", "şuur akışı", "doğrudan iç konuşma" terimleriyle de anılan bilinç akışı, edebiyatta modern anlatım yöntemlerinden biri olarak kabul edilir (Odacı, 2009: 609). Mehmet Tekin'e göre, roman sanatında bir devrimin başlangıcıdır (Tekin, 2001: 186). Hakan Sazyek tarafından "Romanda figürlerin iç dünyalarını aracısız ve bütün karmaşasıyla aktarmak amacıyla, çağrışıma dayalı olarak birbirini izleyen ilintisiz cümleler şeklinde uygulanan bir tekniktir." (Sazyek, 2015: 76) biçiminde tanımlanan bilinç akışı, özellikle dilin sıra dışı kullanımıyla, düzensiz anlatımlarla dikkati çeker. Kişilerin iç dünyalarında olup bitenleri, düşünceleri, duyguları, bilinçaltında gizlenenleri anlatmak için kullanılan bu yöntemle yazarın saf dışı bırakıldığı, okurla baş başa kalan kahramanın, aklından geçenleri kendi ağzından, birtakım dil kurallarını yok sayarak rastgele aktardığı görülür. Bu yönüyle kahramanın kafasının içini okura seyrettiren bir tekniktir (Moran, 2002: 82) ve daha çok psikolojik eserlerde tercih edilir. (Karabulut, 2012: 1377). Bilinç akışıyla bireyin iç dünyasına girilmekte, düşünce ve duygularına ortak olunmakta; bu da kişinin psikolojik anlamda çözümlenebilmesine olanak sağlamaktadır. 3

Türk edebiyatında bilinç akışı tekniğinden yararlanan yazarlardan biri de Selim İleri'dir. Nesrin Mengi, İleri’nin romanlarında daha çok birinci tekil ve üçüncü tekil anlatıcının tercih edildiğini; birinci tekil anlatıcılığına dayalı olan romanlarında, kişilerin bilinçaltına daha çok yer verildiğini; bu eserlerde anlatılan her şeyin kahramanların bilinç süzgecinden geçirilerek sunulduğunu; üçüncü tekil

3 Bilinç akışı tekniği ile ilgili ayrıntılı bilgi için bk. Sazyek, H. (2015). Roman Terimleri Sözlüğü - Roman Sanatından Yüz Terim. Ankara: Hece Yayınları, ss. 76-81; Tekin, M. (2001). Roman Sanatı -Romanın Unsurları 1. İstanbul: Ötüken Neşriyat, ss. 269-275; Çetişli, İ. (2004). Metin Tahlillerine Giriş / 2 - Hikâye-Roman-Tiyatro. Ankara: Akçağ Yayınları; ss. 108-109; Çetin, N. (2013). Roman Çözümleme Yöntemi. Ankara: Öncü Kitap, ss. 180-182; Kale, Ö. (2015). Edebiyatta Bilinç Akışı Tekniğine Başvurulma Sebepleri Üzerine Bazı Dikkatler. NWSA-Humanities, 10 (2), 88-93; Odacı, S. (2009). Ulysses ve Tutunamayanlar'da Bilinç Akışı Tekniği. Turkish Studies, 4 (1), 605-684 vb. 
Language and expression features based on stream of consciousness technique in Selim İleri's Hepsi Alev novel / H. Aydın (pp. 106-122)

anlatıcılığına dayalı olan eserlerinde de yer yer iç konuşma ve bilinç akışı teknikleri kullanılarak kişisel anlatıma başvurulduğunu ifade eder (Mengi, 2012: 132-133). Bu çalışmanın konusu olan Hepsi Alev adlı romanında da yazar, genel olarak birinci tekil anlatıcıyı tercih etmiş ve bilinç akışı yöntemini başarılı bir şekilde kullanmıştır. Romanda, Bizans İmparatoriçesi Atinalı İrene'nin birkaç günde hatırlanan hayatı, bilinç akışı yöntemiyle aktarılır (Öğüt, 2007: 34). Eserde İrene, sürgündedir ve bu dönemde aklından geçenleri anlatmakta; çağrışımlar yoluyla hayatını gözden geçirmektedir. Anlatım yöntemi olarak seçilen bilinç akışı tekniği, İrene’nin iç dünyasının görülmesini sağlamıştır. Mustafa Karabulut, bu yöntemle yazarların kronolojik zamana bağlı kalmadan, insanın bilinçaltının derinlerine inebildiklerini belirtir (Karabulut, 2012: 1377). Okur, İrene'nin hayatını öğrenirken aynı zamanda onun düşüncelerine, duygularına, itiraflarına, iç hesaplaşmalarına da ortak olur. Bilinç akışı yöntemiyle geçmiş ve konuşma anı birleştirilerek İrene bütün yönleriyle okura sunulur. 4

Eserde bilinç akışı tekniğinin yanı sıra iç konuşma yönteminden de yararlanıldığı dikkati çeker. İç konuşma da bilinç akışı gibi kahramanın iç dünyasını okura doğrudan yansıtan bir tekniktir. Araştırmacılar, dilin kullanımı bakımından bu iki yöntemi birbirinden ayırır. Her iki yöntemde de kişinin düşüncelerinin, duygularının sergilenmesi esastır. Ancak iç konuşmada, dil bilgisi bakımından düzgün, söz dizimi kurallarına uygun ve aralarında mantıksal bağ bulunan cümlelerin kullanıldığı (Moran, 2002: 82); bilinç akışı tekniğindeyse dil bilgisi, akıl ve mantık kurallarına bağlı kalınmadığı için anlatılanlar arasında bir mantık ve düzen bulunmadı̆̆ı, cümlelerin de bozuk ve düzensiz olabileceği ifade edilir (Çetişli, 2004: 108; Çetin, 2013: 181). Bazı araştırmacılar, bilinç akışının da bir tür iç konuşma olduğunu dile getirmişler ancak amaç aynı olsa da dil malzemesi farklı olduğu için ayrı ayrı değerlendirilmeleri gerektiğini belirtmişlerdir. Örneğin Tekin'e göre bilinç akışı, bireyin duygu ve düşüncelerinin seri fakat düzensiz olarak biçimlenen bir iç konuşma biçiminde verilmesidir (Tekin, 2001: 269). Sazyek de bilinç akışına iç konuşmanın düzensiz hâli denebileceğini ifade eder (Sazyek, 2015: 76).

Rahime Çokay Nebioğlu, modern eserlerde bilinç akışının genellikle iç konuşmalarla birlikte kullanıldığını belirtir (Çokay Nebioğlu, 2019: 1349). Hepsi Alev romanında da bu iki tekniğin sınırları kesişmektedir. Nurullah Çetin, iç konuşmada kişinin mantığının, aklının kontrolü altında olduğunu, kahramanın ne dediğini bildiğini, düzgün cümleler kurarak kendisiyle konuştuğunu ifade eder (Çetin, 2013: 181). İrene de bazen böyledir. Uygun cümlelerle aklından geçenleri anlatır. Bu bakımdan bazı bölümler, iç konuşmayı andırır. Yine de bu bölümlerde bile kimi zaman çağrışım yoluyla aklına gelen bir olaya, duruma aniden gönderme yapabilmektedir. Bazen de, özellikle kendisini çok fazla üzen olayları hatırladığında, zihni bulanıklaşır, geçmişle yaşanan an iç içe geçer; düşünceler karışık bir biçimde sunulur. Bu açıdan İrene'nin aklından geçenler her zaman aynı kullanımlarla sunulmadığı için bilinç akışı ve iç konuşma, romanda iç içe geçmiştir denebilir. Nitekim İleri de "Her Gece Bodrum" adlı romanını yazarken bu iki tekniği bilinçli ve amacına uygun olarak birlikte kullandığından söz eder:

\begin{abstract}
"İç konuşmaları, yer yer bilinç akışını, biçim açısından, bir bezek olsun diye kullanamazdım. Çoğu romanda gereksiz yere kullanıldığından yanılgılı iç konuşma anlayışına kapılmamak için, yazdıklarımı temellendirmeyi gereksindim. Kişilerim içedönük, saplantıll, ruhsal dengesizliklerle yüklü kişilerdi. Zaman zaman çıldırının eşiğine dek varıyorlardı. Yalın görünen yaşamları alabildiğine karmaşıktı. İç konuşmayı, çıldırının belirmediği, ama iç çatışmanın yoğunlaştığı durumlarda kullandım." (İleri, 1977: 251)
\end{abstract}

Yukarıda belirtildiği üzere bilinç akışı tekniğinin kullanıldığı eserlerde çoğu zaman dil bilgisi ve noktalama kurallarının, mantıksal bağlantıların göz ardı edildiği dile getirilir. Ancak hangi kurallara

$4 \quad$ Romanla ilgili inceleme için bk. Maktal Canko, D. Y. (2019). Türk Edebiyatında Bizans İmparatoriçeleri ve Selim İleri’nin "Hepsi Alev" Romanı. RumeliDE Dil ve Edebiyat Araştırmaları Dergisi, 16, 308-318. 
uyulmadığı ya da nasıl bir anlatımın tercih edildiği, dille ilgili çalışmalarda ayrıntılarla ele alınmamıştır. Bir dil incelemesi olarak hazırlanan bu çalışmada, bilinç ve bilinçaltı düzleminde var olanların dilde nasıl varlık bulduğu ortaya konmak istenmiş; bu amaçla bilinç akışı tekniğinden kaynaklanan kullanımların dil bilgisi kuralları çerçevesinde değerlendirilmesi hedeflenmiştir. Örneklem olarak Selim İleri'nin Hepsi Alev romanı seçilmiş, doküman incelemesi yöntemiyle eserdeki dil kullanımı değerlendirilmiş; romandan alınan örneklerle bilinç akışının dili ortaya konmaya çalışılmıştır.

\section{Hepsi Alev'de bilinç akışı tekniğine dayalı dil ve anlatım özellikleri}

Hepsi Alev romanında dil kullanımına bakıldığında bilinç akışı tekniğine dayalı olarak bağdaşıklık ve tutarlılık sorunları içeren söylemler ile dilde en az çaba ilkesine aykırı örneklerin olduğu görülür. Bunların yanında anlatım tekniğinin getirisi olarak alınabilecek, kurallara aykırı olmayan bazı kullanımlar da sıklıkla tercih edilmiştir. Ayrıca noktalama işaretlerinin bilinç akışını yansıtmak adına özellikli biçimde kullanıldığı da dikkati çeker. $\mathrm{Bu}$ kullanımlar, aşağıda örneklendirilerek değerlendirilmiştir.

Bilinç akışı yöntemine bağlı olarak birbirinden anlamca kopuk cümlelerin bir arada kullanılması, dilde tutarlılık ilkesine aykırı kullanımların ortaya çıkmasına yol açmıştır:

Tutarlılık, “derin yapıda oluşan anlamlar arasındaki mantıksal bağlantıdır” (Onursal, 2003: 14). Buna göre cümleler, anlamsal bir bütünlük göstererek bir araya gelirler. Hepsi Alev romanında bilinç akışı tekniğine dayalı olarak bu ilkeye aykırı kullanımlar, sık sık görülür. Bu, okurun karşısına iki biçimde çıkar: İrene, öncelikle geçmişten şimdiye, şimdiden geçmişe hızlı geçişler yaptığı için anlatımda dağınıklıklar meydana gelmektedir. Öte yandan sadece geçmişe dair anılarına yer verdiği bölümlerde bile konudan konuya atlayabilmektedir.

\section{Sürekli geri gidişler ve ana dönüşler, anlatımda dağınkkhğa sebep olmuştur:}

İrene, Prinkopo'da sürgündedir. Bir yandan anı yaşar, bir yandan da geçmişi düşünür; yaptıklarını, yapamadıklarını, yapmak istediklerini, anılarını hatırlar. Bu, onun geçmişle şimdiyi içe içe anlatmasına neden olur. Sürekli geçmişe gidişler ve yaşanan zamana dönüşler, anlatımın da dağınık olmasına sebep olmuş, cümleleri anlamsal olarak aynı çatı altında toplamaya yarayan ilişkilerden biri olan "ortak zaman” ilişkisinin kurulamamasına yol açmıştır. Bu da cümle topluluklarının tutarlı bir bütün oluşturmadığını göstermektedir.

Örneğin sürgündeyken yanındaki hizmetçi kız Demo’ya “... Şehirde, Doğu’dan ve Batı’dan gelen gemileri görmüş müydün Demo?” (İleri, 2007: 31) diye sorduğunu belirtir. Ardından gözlerini kapadığını, hayalinde gördüklerini, deniz tutkusunu, tasvirseverleri ve bir anısını anlatır:

“(...) Neydi beni denize çeken, ufukta, enginde? Gitmek isteği mi, açılmak enginlere, çekip uzaklaşmak mı, kaçmak; limanlara gelirken urbalar kuşandığım gibi, hayatımı da mı değiştirmek? Asla. Ben burdayken, Ebedî Şehir'de, biliyordum ki, yarın da burada. (...)

Kaçanlar oldu. Tasvirseverler arasından. (...)

Bir asker sormuştu, genç bir çocuk, yüzü silinmiş. Fakat sorusu aklımda: 'Rüzgâr mı iyi geliyor?' (...)” (İleri, 2007: 31-32)

Sonra birden sürgün zamanına döner ve Demo'nun cevabından söz eder:

““Araba yarışlarını gördüm’ dedi. Hipodromdaki günlerini özlemiş bir ifadeyle.” (İleri, 2007: 32) 
Language and expression features based on stream of consciousness technique in Selim İleri's Hepsi Alev novel / H. Aydın (pp. 106-122)

Böylece soru-cevap cümlelerinin arasına diğer düşüncelerin, anıların yerleşmesi, anlatımda dağınıklığa sebep olmakta; cümleler arasındaki bağlantıları görmeyi zorlaştırmaktadır.

Romanda iç konuşma biçiminde anlatılan olaylar, çoğu zaman bilinç akışı tekniğiyle bölünür. Aşağıdaki örnekte sürgünden önceki yaşantısından söz ederken birden yaşadığı ana döner; akşam olduğunu, kargaların uçtuğunu anlatır:

"Bazı günler o kadar tiksindim ki, kaçtım, kendime ve tasvirlerime sığındım, dar vakitler. Dudaklarım, İsa'nın dudaklarına kavuştu.

İsa'yı öptüm. Onun da beni öptüğ̈nü hissettim.

Akşam arttıkça, kalbimdeki ağrı da artıyor.

Siyah, korkunç kargalar uçtu. Öyle bir halleri vardı ki, akşamdan ürktüklerini düşündüm. Akşamdan kaçıorlar, besbelli.

Kaçmam için sebep kalmadı. Geçmişteki hayatım, çevremde, dört bir yanımda bomboş, beyhude duruyor. Konstantinopolis’in zafer nâralarıyla sarmaş dolaş uğultusu dindi.” (İleri, 2007: 22)

Eserde cümlelerin dağınıklığı, çoğu zaman çağrışımlardan dolayıdır.

"Çünkü şuur akımı, bilinç baskısından kurtulan insan bilinç altının, serbest bir şekilde dışa sızmasıdır. Söz konusu sızma, çok büyük ölçüde çağrışımlara dayanır.” (Çetişli, 2004: 108)

$\mathrm{Bu}$, İrene tarafından da dile getirilir: "Adonis aklıma gelmeseydi, nergis de sümbül de gelmeyecekti" (İleri, 2007: 16). Yukarıdaki söylemde görülen karışıklığın nedeni de budur. Örnekte, geçmişte insanlardan kaçtığı zamanları anlatırken gördüğü kargalar da ona kaçıyor gibi gelmiştir. Bu benzerlikten dolayı geçmiş ve şimdiki zaman, ani bir geçişle bir araya getirilmiş olmaktadır.

Aşă̆ıdaki örnekteyse yağmurun sesinden etkilenip geçmişe gider, pişmanlıklarını dile getirir, iç hesaplaşma yapar. Ancak bir ara konudan bağımsız bir biçimde "Evet, uysal... hep uysal yağmurun sesi.” cümlesini araya sıkıştırır. Sonra kaldığı yerden devam eder:

“Uysal yağmurun ezgisini dinledikçe pişmanlık ağır basıyor. Oysa gözlerimi kapar kapamaz, eski günlerin saltanatı. Hangisiydim? Yolum nasıl değiști? Atina'dan getirilmiş gencecik kız, mermer heykellerin sessiz güzelliği yerine, Konstantinopolis’in hayhuyuna, hatta hipodromun bayağılığına niçin battı?

Evet, uysal... hep uysal yağmurun sesi.

Oysa İsa’nın sözünü dinlememiştim. Benim krallığım bu dünyada sanıyordum.” (İleri, 2007: 96-97)

\section{Sadece geçmişi, anılarmı anlattı̆̆ı bölümlerde bile konular arasında sıçramalar, ani geçişler görülebilmektedir:}

İrene'nin deyişiyle anılarının "fişkırması" (İleri, 2007: 150), cümlelerin konu bütünlüğü gözetilmeden bir araya gelmesine, âdeta saylklamaya neden olmuştur. Hande Öğüt, Hepsi Alev'in İrene'nin duyumsamaları, içsel hayat ile dışsal hayat arasındaki hezeyanları üzerine temellendiğini ifade ederek bu duruma dikkat çeker (Öğüt, 2007: 33). Zaten Tülay Karatekin'in de dile getirdiği gibi, bilinç akışı bir sayıllama hâlidir:

"Bilinç akışı tekniği, yazarın kurgusal bir metinde anlatıcının ya da karakterin aklından geçenleri herhangi bir mantık ölçüsüne bağlı kalmadan, zihninde anlık yanıp sönen düşünceleri, sayıklama edasıyla kâğıda dökmesi olarak tanımlanır.” (Karatekin, 2019: 216) 
Buna uygun olarak aşağıdaki örnekte tasvirseverlerin, Kalinikos'un, Thalia'nın, İrene'nin aklına geldikçe karışık biçimde verildiği görülür:

“Tasvirsever pek çok rahibe, erkek kılığına girerek, çöle kaçtı. Işık Şehir’den. (...) Kalinikos, hangi dine, hangi kiliseye inanıyordu... Küçük bir kızı yalnız bırakırken, Thalia, mermerin kaskatılı̆̆ı mıydı yoldaşın? Her şey karışıyor.” (İleri, 2007: 153)

Hatta İrene de bu dağınıklığın farkındadır:

“Kelimelerim eksik püksük. Düşündüklerimi derli toplu dile getiremiyorum.” (İleri, 2007: 113)

Kahraman, kimi bölümlerde anılarını sunarken olayları düzgün bir sırayla anlatır; bazı yerlerdeyse bilincini kaybetmiş gibi davranıp kendisinde iz bırakan olaylara ait cümleleri, ifadeleri dağınık biçimde aralara serpiştirir. Örneğin İrene, Azize Efimia'nın mezarının tahrip edilmesinden söz ederken birden kayınpederinin kendisine tacizde bulunduğunu hatırlar. Mezarın tahrip edilmesi, "siyah bir gece"de olmuştur. İrene de böyle bir gecede tacize uğramıştır. Dolayısıyla "siyah bir gece", onda bu anıyı çağrıştırmış olmalıdır. Bu yüzden yaşadığı tacizi anlatan cümleleri -ki bunlar, bilinç akışı tekniğinden kaynaklanan yüklemsiz kesik cümlelerdir- araya sokar:

\begin{abstract}
“Kayınbabamın babası Çoban Leon'un saltanatı sırasında mezarı kirletilmiş Azize Efimia benim için onmaz bir kalp ağrısı, kalp yarasıydı. En gözü dönük tasvirkırıcı tarihçilerin bile ölçülü dille yazdıkları bu kepazelik, bu günahkârlık, Efimia'nın mucizelerle dolu ölü bedenini yeryüzünün, insan denen pespayeliğin merhametsiz ellerine teslim etmiş. Tahrip etmekten ötesini bilmeyen ahaliye, Çoban Leon kılavuz olmuş. Siyah bir gecede...
\end{abstract}

... Oğlu Gübre Konstantinos, siyah bir gecede, baba şefkatiyle yaklaştığı genç kızın göğüslerini... elimi tutan elin sıcaklığı ve sıcak elin kasıklarımda...

Efimia'nın ölü bedeni, siyah bir gecede, mezarından çıkartılmış. Çiçeklerin rayihasıyla yıkanmış bu bedeni Leon denize attırmış." (İleri, 2007: 144)

"Dört beyaz atın çektiği arabam..." (İleri, 2007: 36) ifadesiyse romanda İrene'nin imparatoriçelik günlerine duyduğu özlemin simgesi gibidir, laytmotif biçiminde sürekli gündeme gelir. Bu söz, ona imparatoriçe olduğu günü, gücünü, görkemini hatırlatmaktadır: "Dört beyaz atın çektiği saltanat arabamda, Aziz Havariler Kilisesi'ne giderken, Ebedî Şehir zaferimle inlemişti” (İleri, 2007: 133). İrene'nin bilinçaltındaki bu özlem, söz konusu söylemin konuların arasına serpiştirilmesiyle sürekli gündemde tutulur. Bu yapılırken konu bütünlüğü bozulduğu için alıcıya sayıklama hâli gibi gelir:

"Demo daha birçok şey anlattı. Yaşamına dair. Bilmediğim Bizans’a dair. İmparatorların birer yüzkarası olduğunu...

... Dört beyaz atın çektiği görkemli saltanat arabama!..

'Demo! Biraz daha şarap! Tanrı aşkına...' Sesim usul usul kısıklaşıyordu. Git git daha ürkek...” (İleri, 2007: 102-103)

Aşağıdaki örnekte de aynı söylem yer alır:

“Anne değildim. Basileus. Basileus İrene. Basileus İrene’ydim.

Yağmur hatırlıyor, dolu.

Hem, kimse kimsenin acısını bilemez. Birçok acıyı sildim.

Oğlum Konstantinos'un gözlerine...

...Dört beyaz atın çektiği arabam! Altın ve ipek esvaplarım belimi bükemiyor. İsa'ya falan inandığım yok. Ebedî Şehir, İrene’yi ‘İsa’nın biricik müttefiki’ diye alkışlıyor.” (İleri, 2007: 76) 
Language and expression features based on stream of consciousness technique in Selim İleri's Hepsi Alev novel / H. Aydın (pp. 106-122)

Asıl bilinç akışı, roman biterken görülür. İrene'nin bütün anıları birbirine karışmıştır. Geçmişteki olaylarla sürgünde yaşamakta oldukları, karmakarışık biçimde aklından geçer. Kahraman, âdeta deliliğin eşiğine gelmiş durumdadır. Cümleler, dil bilgisel açıdan genellikle kusurlu değildir. Ancak konu bütünlüğ̈̈ olmaması, tutarlılık ilkesine uyulmadığını gösterir. Uzun bir akış biçiminde verilen bu bölümde sözü edilenlerin bir kısmı şöyledir:

“(...) Oğlunun gözüne hangi anne diyordu bir yoksul balıkçı karısı. O annenin adı İrene. Ben, basileus İrene. Kalbimde ölümün ayazı. Yitik ülküler ecesi. (...) Beni zehirliyorlar. Keskin belleğim çöktü. Atina'dan gelirken, siyah bir gecede, yaz gecesi, bu bir nakarat... Kayınbabam göğüslerimi... Hazar Leon'un daima kocası oldum; oğlumun naibesi... Demo benden korkuyor. Demo, 'Kendi isteğimle rahibe olacağım' dedi. (...) Lesbos'ta yanımda kim olacak, kim bakacak bana? İnsanları tanıyamıyorum. Aşağıda hadımlarım var. Beni satmışlardı, Nikeforos'u kandırarak. (...) Hep sarhoştum. Şarap sürgünde tek yoldaşım. (...) 'Size ihanet eden karanlıklar içinde kalsın!' ben söylemiştim. (...) Hipodromda. Aziz Havariler Kilisesi’ndeki tören. (...) Siz başrahibe Margarito değil misiniz? Burada beni zehirlediler. Başrahibe nerede? (...) Konstantinos erguvan renkli odada büyüyor. Elbiselerim erguvan rengi. Yalnızca erguvanî ipekliler giyerim. Gözlerini sonsuza dek karanlıkta bırakınız! Sizlere ihanet edenler... Perdelerim uçuşuyordu, Yeni Saray'da, tarihçilerin kimliğini çözemediği bir adamın sarayının yıkıntıları üstüne inşa ettirdiğim, perdelerime koşmuş ve sığınmıştım, sarılmış, ağlamış İrene. İsa'nın karanlığını bütün gece, sonra hep gece, onun bendeki gecesi. Sabah Bizans'ın basileus'u, Tanrı'nın yeryüzündeki vekiliydim. Dört beyaz atın çektiği saltanat arabamda, muzaffer basileus Ebedî Şehir'de yol alıyor, ipek ve altın, ahaliye avuç avuç para firlatıyor. (...)" (İleri, 2007: 174)

Bazen de göstergeler arasına çok fazla farklı bilgi girdiği, metin içinde uzak gönderimler söz konusu olduğu için anlaşılmada zorluklar ortaya çıkabilmektedir. Örneğin romanın başında bir askerden söz edilir:

"Bir asker sormuştu, genç bir çocuk, yüzü silinmiş. Fakat sorusu aklımda: 'Rüzgâr mı iyi geliyor?'

Rüzgârlı bir gündü. Çok zaman geçti.

'Deniz' demiştim.

Deniz asi yaradılışları kamçılar.

Askerin rüzgâra, denize, yardıma... Sormadım. Onu bir daha herhalde görmedim.” (İleri, 2007: 32)

$\mathrm{Bu}$ asker, roman ilerledikçe bilinç akışının etkisiyle anlatılan konuyla ilgili olmayan pek çok yerde okurun karşısına çıkmaktadır. Örneğin,

“İlk gecemi de siliyorum belleğimden. İrene'ye âşık olduğunu söyleyen Leon’u, aşkı. Çı̆̆lı̆̆ı bırakıyorum İrene'ye, hiçbir zaman haykırılmamış.

Balıkçılar... Rüzgârları soran asker...

Yol aldığıma inandığım için, Leon'un aşkına da inanıyordum." (İleri, 2007: 43-44)

biçiminde verilen söylemde "rüzgârları soran asker" ifadesinin, art göndermeyle daha önce aralarında konuşma geçen askere gönderme yaptığı anlaşılır. Aynı asker, sayfalar sonra yine "rüzgârı soran asker" olarak gündeme gelir:

"Kimse yoktu. Hiçbir zaman. Aileniz yoktur, anababanız. Kocanız yoktur. Oğlunuz... evladınız... evlatlarınız size ihanet ederler. Hadımlarınız sizi satarlar. Önünüzde eğilen, yarın size... Boş ver İrene. Boş veriyorum.

Öyleyken, hep, dört beyaz atın çektiği...

Ya da, rüzgârı soran asker, Bizans'ın yok olacağını söyleyen rahip...

Kimseniz yoktur. Onlar da kimsem değildi.” (İleri, 2007: 110-111) 
Ancak araya pek çok bilginin, konunun, olayın girmesi, bu göstergenin unutulmasına neden olacağı için alıcının gösterileni anlaması zor olmakta, metin tutarlılık ilkesinden uzaklaşmaktadır. Bu cümlelerde, sözü edilen askerin neden sık sık gündeme geldiğiyse daha sonra anlaşllır. Asker, İrene'nin belleğinde yer etmiştir. Bilinç aktıkça o da gündeme gelmektedir. Romanın sonuna doğru, İrene'nin hayatında iz bırakan yedi kişiden birinin de bu asker olduğu görülür:

"Genç asker. Kalinikos. Hiçbir anne oğlunun gözlerine... diyen dul kadın. Manuel. Uzaklardan Prinkopo’ya gelmiş kadın. Maria. İoannes. Hayatım boyunca yedi kişi!” (İleri, 2007: 154)

\section{Eserde bilinç akışı tekniğine bağlı olarak oldukça sık kullanılan yüklemsiz kesik cümleler nedeniyle anlamın çoğu zaman kapalı kalması da dikkat çekici bir başka özelliktir:}

Kurucu ögesi bulunmayan, bütün alıcılar tarafından ortak biçimde anlaşılabilecek bir yüklemi olmayan cümleler, yüklemsiz kesik cümle olarak tanımlanmaktadır. Kesik cümleler, sözü daha etkili kılmak için sıklıkla tercih edilirler. Çünkü "Kesik tümce, söze duyusallık kazandırır; imgelem gücümüzü çalıştırır" (Dizdaroğlu, 1976: 274). Hepsi Alev romanında oldukça fazla kullanılan kesik cümlelerse anlatım tekniğinin getirisi olarak görülmektedir. İrene, zihni karışık olduğu için sık sık cümleleri tamamlamadan başkalarına geçer. Yarım bırakılan yüklemsiz kesik cümle kuruluşundaki bu yapılar, duygu aktarımında rol oynamakla birlikte çoğu zaman anlamın soyut, kapalı kalmasına neden olur.

"Götürdüler.

Gübre Konstantinos'un zindanları gibi benim de zindanlarım. Başka çare yoktur. Zindansız iktidar yoktur." (İleri, 2007: 76)

Yukarıdaki örnekte "Gübre Konstantinos’un zindanları gibi benim de zindanlarm." ifadesi, yüklemi olmayan kesik cümle kuruluşundadır. Alıcı, bu cümleyi bağlama uygun olarak "Gübre Konstantinos'un zindanları gibi benim de zindanlarm vardı/oldu/hazrdd." vb. biçimde algılayacaktır. Ancak bütün alıcılar, bu boşluğu aynı biçimde dolduramadıkları için anlamda bir kapalılık söz konusudur. Burada yüklemin kullanılmamış olması, İrene'nin duygu durumuna bağlanabilir. Üzüntüden, mutsuzluktan, yorgunluktan cümlelerini bile tamamlayamamakta, aklından geçenler kesik kesik varlık bulmaktadır.

“'Sürgün kadın' ben olmalıyım.

Acı acı güldüm. Dört beyaz atın çektiği arabamda gidiyorum. Hipodromdaki töreni en erken sona erdiren basileus! Hiçbir şey beklemediğimi kendilerinden, hiçbir şey!, ahaliye, sürü kalabalığa.

Meşe ağaçları. Çınar ağaçları.

Ayakta duruyorum, dimdik. Ve halk ve bütün Bizans.

Baileus'lar yok olacaklar: Müthiş bir korkuyla sarsılıyorum. Dimdik. Atkestanesi, çınar, meşe bizden, insanoğlundan çok daha uzun ömürlü.” (İleri, 2007: 44)

İrene, sarhoşluğun da etkisiyle birçok şey hatırlar; bunları kesik cümlelerle ve anlam bütünlüğü gözetmeden bir araya getirir. Yukarıdaki örnekte de altı çizili yüklemsiz kesik cümlelerle birlikte aynı çatı altında anlamsal olarak nasıl buluşturulması gerektiği belli olmayan diğer ifadeler, tutarlı bir bütün görmeye engel olmaktadır.

"Utanç içinde geri çekildim.

Kandiller bana şimdi nefretle bakan bir genç adamı... bir yanıp bir sönerek, tutuşarak ve ölerek.

Hazar Leon'dan kurtularak ayağa kalktım." (İleri, 2007: 43) 
Language and expression features based on stream of consciousness technique in Selim İleri's Hepsi Alev novel / H. Aydın (pp. 106-122)

söylemindeki altı çizili ifadeler de alıcının net anlama ulaşmasını engelleyen yüklemsiz kesik cümleler olarak dikkati çekmektedir. Anlam, son derece belirsizdir, kapalıdır.

“Prinkopo'da, gecemdeki kandile, ölmek için bir pervane dönenip duruyor. Oğlumun ölümünden söz açarken. Çamlıktan geniz yakıcı çam kokusu. Pervane yanıp ölecek. Babası Hazar Leon beni gebe bırakmamıştı. Erkek kimliğine bürünerek, bir solucandan farksız, kendi kendimi dölledim. Kandilimden yangın bekleyen pervaneyle gözlerinin ıșığını söndürdüğüm oğlum, biri çırpınırken, biri ölmüșken, bana... Kandili söndürmeyeceğim. Pervane de tutuşacak.” (İleri, 2007: 176)

Bu örnekte de çağrışım yoluyla bir araya gelen cümlelerin içinde yüklemsiz kesik cümle kullanılmıştır: "Kandilimden yangın bekleyen pervaneyle gözlerinin ışığını söndürdüğüm oğlum, biri çırpınırken, biri ölmüşken, bana...” Bu, dil bilgisel açıdan bir kusur değildir ama anlamayı zorlaştırır. Anlatımı daha çarpıcı hâle getirmek, alıcıyı da konuya dâhil etmek gibi amaçlarla bu tür yapılardan yararlanılır. Burada İrene'nin oğluyla pervane eş tutularak aralarındaki benzerliğin hayal edilmesi, İrene'nin her ikisinin de sonunu getirdiğinin düşünülmesi istenmiş olmalıdır. Ayrıca İrene'nin, pişmanlıklar yaşadığı; bazı olayları kendi zihninden bile uzaklaştırmak istediği için düşünceden düşünceye atladı̆̆ı; bunların metinde kesik cümleler olarak sunulduğu da düşünülebilir.

“Ben, kaç dağ rüzgârını... Ozanın söylediği ‘dağ rüzgârı' mıydı? Kayıtsız, aldırıșsız; șaraptan bir yudum daha. Demek, düşüş en son noktasına ulaştı.” (İleri, 2007: 102)

söyleminde de İrene, aklına bir soru geldiği için ilk cümleyi (Ben, kaç dağ rüzgârını...) yarım bırakmış, tamamlamamış; sonraki altı çizili yapıda da (Kayıtsız, aldırışsız; şaraptan bir yudum daha.) yine yükleme yer vermeyerek kesik cümle tercih etmiştir.

Kesik cümleler, bazen de kesik bir ağlama gibidir:

“Gelgelim berbat bir gözyaşı sağanağı: Daha dün, daha Atina'dan, bin yılın mermer heykellerinden ayrılırken, Thalia, annem babam, kardeşlerim... tahtın varisine eş olarak... ülkülerim! Bizans'ta tasvirseverlerin imparatoriçesi olacaktım! Ezilen insanlara, yoksullara, düşkünlere... Daha dün! Hayallerim ve umutlarımla...” (İleri, 2007: 170)

Ek bilgi veren ara cümlelerde bile kesiklik görülebilmektedir:

"Yerlerde sürüklenen, sürünen balıkçılar, o zavallı ya da küstah kadın, kocasını denizlerde ölüme..., herhalde yalnızca çizmelerimi görebiliyorlar.” (İleri, 2007: 180)

\section{Kahramanın, aklına gelenleri kesintili biçimde sunması, gereksiz eksiltilerle pek çok yüklemli kesik cümle ortaya çıkarmıştır. Bu da dilde en az çaba ilkesinin göz ardı edildiği anlamina gelir:}

İrene, kısa cümlelerle düşüncelerini ifade eder gibi görünür. Ancak bu kısa cümle görünümündeki ifadelerin çoğu, eksiltili yapıdır. Romanda cümle ögelerinin parçalanması, bunların ait olduğu cümlelerden ayrılarak yeni birer cümle gibi sunulması, böylece kısa ve kesik cümlelerin ortaya çıarılması, sık başvurulan bir uygulama olarak dikkati çeker.

“Hepi topu yedi kişi mi? Sayabildiğim. Mutlaka eksik sayı.” (İleri, 2007: 155)

örneğinde "Sayabildiğim hepi topu yedi kişi mi?” biçiminde kurulabilecek cümlede özne olarak yer alması gereken sözcük (sayabildiğim), ikinci bir cümle gibi sunulmuştur. Dil bilgisel açıdan bunun yüklemli kesik cümle olduğu görülür; yani yüklemi yüzey yapıya çıkarılmamış, derin yapıda bırakılmıştır. Cümlelerdeki boşluklar tamamlandığında ortaya şöyle bir görüntü çıkar: 


\section{1. sayabildiğim hepi topu yedi kişi mi}

\section{2. sayabildiğim hepi topu yedi kişi mi 5}

Böylece, kesik kesik sunulan bilgiler, gereksiz tekrarlarla cümle sayısının artmasına yola açmakta, bu da dilde en az çaba ilkesinin gözetilmediğini göstermektedir. Oysa "'Dilde tutumluluk, dil ekonomisi' adlarıyla da bilinen bu ilkeye göre, söylenmek isteneni en kısa yoldan, gereksiz kullanımlardan kaçınarak vermek esastır" (Aydın, 2011: 1). Tek cümlede verilebilecek bilginin, tekrar oyunlarının gücünden yararlanılarak burada olduğu gibi iki ya da daha fazla cümle biçiminde sunulması, hem alıcının bu bilgiye odaklanması içindir hem de zihni bulanık olan İrene'nin her bilgiyi zamanında hatırlayamadı̆̆ını, sözcüklerin kesintili biçimde aklına geldiğini gösterir.

Kendini ifade edecek sözcükleri bulamadığını İrene de söyler:

“İrene yalnızdı. Ancak o anlatabilir. Mücadelesini. Kelimeleri bulabilsem. Ayışığında.” (İleri, 2007: 132)

Bu bilgi, onun kesintili konuşmasını, cümlelerden ayrılan ögeleri açıllar niteliktedir. İrene, sözcükleri, sözcük öbeklerini, dil birimlerinin sıralanma kurallarını gözetmeden aklına geldikçe dile getirir.

"İrene de kadına baktı: Yüzü kırış kırış, canı yanmış. Yükseliyordum. Altın kartalların bezediği pabuçlarım; tekme atmak geçti içimden. Suratına. Yoksul kadının.” (İleri, 2007: 75-76)

Yukarıdaki söylemde de aynı durum vardır. Sözcük öbekleri bile bölünerek üç cümle ortaya çıkarılmıştır:

\section{1. yoksul kadmm suratına tekme atmak geçti içimden}

\section{2. yoksul kadınm suratına tekme atmak geçti içimden}

\section{3. yoksul kadının suratına tekme atmak geçti içimden}

Burada ögelerin ayrı cümleler gibi verilmesi, İrene'nin sözcükleri hatırlamakta zorluk çektiğini göstermenin yanı sıra sunulan üç bilginin derecelendirildiğini de işaret eder. İrene'nin içinden geçen tekme atma isteğinin surata yönelmesinin çirkinliğini okura göstermek, hatta buna şaşkınlık duygusu katmak için sadece "suratına" ögesini yüzey yapıda veren ayrı bir cümle kullanılmıştır. Bundan daha acımasız, kötü, çirkin olanıysa tekmenin yoksul kadına atılmış olmasıdır. Bu da ayrı bir eksiltili cümle biçiminde sunulmuştur. Böylece "Suratına." ve "Yoksul kadının." cümleleri, iletinin duygu boyutunun öne çıkmasını, kahramanın ruh hâlinin yansıtılmasını sağlar.

$\mathrm{Bu}$ bölümlerde kullanılan nokta işareti, dikkat çekicidir. Bilindiği gibi nokta, bir duraklama göstergesidir. Bilincin akışındaki kesintileri göstermesi bakımından bu işaret, eserde bilinçli kullanılmış gibi görünmektedir. Tekin,

“(...) bilinç akımı tekniği, bireyin iç dünyasında şekillenen duygu ve düşüncelerin doğal olarak yansıtılması anlamına gelmektedir. Dışa yansıtmada doğallığı korumak isteyen bazı romancılar, akışı engellediğini varsayarak noktalama işaretlerini kullanmamışlardır.” (Tekin, 2011: 273)

diyerek bazı romancıların bilinçli biçimde noktalamasız kullanıma başvurduğunu dile getirir. Hepsi Alev'deyse bu uygulama yoktur. Aksine çok daha fazla, hatta gereksiz nokta kullanımı dikkati çeker.

5 Örnek cümlelerde derin yapıda kalan dil birimleri, koyu yazılmıştır. 
Language and expression features based on stream of consciousness technique in Selim İleri's Hepsi Alev novel / H. Aydın (pp. 106-122)

Serdar Odacı, bilinç akışı tekniği kullanılan iki eseri -James Joyce’un Ulysses romanıyla Oğuz Atay’ın Tutunamayanlar'ını- karşılaştırdığı çalışmasında Joyce’un da bazı bölümlerde bilinçli bir şekilde noktalama işaretlerini kullanmadığını belirtir ve bunun gerekçesini şöyle açıklar:

"Dilin eklemlenmeli niteliği nedeniyle Joyce birden fazla algıyı bilince çarptığı şekliyle verememiştir. $\mathrm{Bu}$ nedenle eş zamanlılığı bir nebze aksettirebilmek için algı zincirinin arasında noktalama kullanmamıştır. Böylelikle okuyucu bu biçimde yazılan kısımları daha hızlı okuma gereği duymaktadır. Noktalamasız kullanım, bilinç akışı tekniği ile bir hareketli resimler arasında bir benzerlik kurulabilir." (Odac1, 2009: 671)

Hepsi Alev'deyse gereksiz yere nokta kullanılarak düşüncelerdeki yavaşlama, hafızanın zayıflığı, aklın karışıklığı, kahramanın ruh hâlinin iyi olmadığı hissettirilmek istenmiş olmalıdır. Bu da bilinç akışı tekniği kullanılan her eserde dil ve anlatım özelliklerinin aynı olmadığının göstergesidir.

\title{
Dil birimlerinin sıralanışındaki bazı bozulmalar, bağdaşıklık ilkesine aykırı kullanımların ortaya çıkmasına yol açmıştır:
}

Bağdaşıklık, dilsel göstergelerin söylemde dil bilgisi kurallarına uygun biçimde yer almasını ifade eder (Üstünova, 2014: 49). Dilin çizgiselliğini bozan kullanımlar, bağdaşıklık açısından sorunludur. Hepsi Alev'de bilinç akışındaki karışıklıktan, düzensizlikten dolayı kimi zaman böyle örnekler görülebilmektedir.

\begin{abstract}
"Perdelerim uçuşuyordu, Yeni Saray'da, tarihçilerin kimliğini çözemediği bir adamın sarayının yıkıntıları üstüne inşa ettirdiğim, perdelerime koşmuş ve sığınmıştım, sarılmış, ağlamış İrene. İsa’nın karanlığını bütün gece, sonra hep gece, onun bendeki gecesi. Sabah Bizans'ın basileus'u, Tanrı'nın yeryüzündeki vekiliydim. Dört beyaz atın çektiği saltanat arabamda, muzaffer basileus Ebedî Şehir'de yol alıyor, ipek ve altın, ahaliye avuç avuç para firlatıyor. (...)" (İleri, 2007: 174)
\end{abstract}

Yukarıdaki örnekte altı çizili bölümdeki "ipek ve altın" ile "avuç avuç para", ahaliye fırlatılan nesnelerdir. Bu birimler, bağdaşıklık kuralları çerçevesinde bağlama öbeği kurup ad görevini üstlendikten sonra çekime girerek yüklem görevindeki "firlatıyor" eylemine bağlanacaklardır. Ancak, bilincin kesintili ve düzensiz akışı, bu öbeğin bozulmasına, araya "ahaliye" ögesinin girmesine neden olmuştur. Bu da sözcük öbeği düzleminde bağdaşıklık sorununu ortaya çıkarır. Dil, ögelerin yer değiştirmesine kurallara uymak koşuluyla izin verir. Hangi sözcük öbeklerinin arasına sözcük / öge gireceği de bellidir. Bağlama öbeği, unsurlarının arasına öge yerleşmesine izin vermez. Öbek, "ipek ve altın, avuç avuç para” bütünlüğünü korumalıdır. Dolayısıyla burada araya öge girişi normal karşılanamaz.

"Yalnızca ince esinti. İnce esinti dumanlı gülleri okşuyor, Kadınlar Manastırı’nın bahçesindeki." (İleri, 2007: 118)

örneğindeyse “dumanl güller" ifadesini nitelemek için kullanılan "Kadınlar Manastırı'nın bahçesindeki” tamlayanı, “Kadınlar Manastırı’nın bahçesindeki dumanl güller” biçiminde kullanılarak tamlananın başına getirilmemiş; cümle bittikten sonra virgül ile ayrllarak sunulmuştur; yani tamlanan (dumanl güller) başa alınmış, araya yüklem (okşuyor) sokularak en son tamlayan (Kadınlar Manastırı'nı bahçesindeki) verilmiştir. Sistem, "tamlayan+tamlanan” sıralamasının bozulmasına geçici olarak izin verir ama ikisinin arasına yüklemin girişi alışılmış bir kullanım değildir.

\section{Yüzey yapıdaki gereksiz tekrarlar da bağdaşıklık sorununa neden olan kullanımlardandır. Bunlar, aynı zamanda dilde tasarrufa gidilmediğini de gösterir:}


İbrahim Karahancı, "Dilin estetiğe düşkünlüğü ve yüzey yapıda tekrara mesafeli duruşu, sözcüğün aynen tekrarını, eş ya da yakın anlamlı sözcük kullanımında sergilenen bilinçsiz tutumu bağdaşıklık sorunu haline getirir." (Karahanc1, 2014: 708) der. Hepsi Alev romanında da, İrene'nin aklından geçenler, dilin ilkeleri ve estetik yapısı gözetilmeden olduğu gibi sunulduğu için, yüzey yapıda fazlaca gereksiz tekrar bulunmaktadır. Zihin, pek çok bilgiyi bir arada barındırır. Bunlar, konuşma ve yazma sürecinde amaca uygun olarak seçilir; dilin kurallarına göre düzenlenir ve sunulur. Ancak romanda bilinçteki düzensizlik yansitılmak istendiği için dil birimleri çoğu zaman herhangi bir seçme, düzenleme işlemine tabi tutulmadan kullanılmıştır. Bu nedenle gereksiz tekrarlar ortaya çıkmış, bunlar da dilde en az çaba ilkesinin ihlaline ve sözcüksel bağdaşıklı sorununa neden olmuştur.

“Demo'dan şarap istedim. Şarap verdi. Şarap içtim. Kırmızı șarabı seviyorum. Rahibelerin bağdan üzüm getirişlerini. Sırtlarında küfeler. Geçen sonbahar, buraya getirildiğimde. Gözlerim yarı kapalı, rahibelere bakardım. Gündüz karardı.” (İleri, 2007: 21)

Yukarıdaki örnekte ardışık ilk dört cümle içinde yüzey yapıda tam tekrar yoluyla "şarap" sözcüğünün kullanılması, dilde tasarruf ilkesinin göz ardı edildiğinin işaretidir. Burada sözcüğün vurgulanmak istenmesinin bu tekrara sebep olduğu düşünülebilir. Ancak vurgulama amacı güdülürken dildeki estetik yapı göz ardı edilmiştir.

"Aslında çınar ağacını andırıyordu; yalnız, yaprakları çok daha küçük. Zaten yaprakları gönül çeliyordu. Varla yok arası esintiye rağmen yapraklar kıpır kıpırdı. Parıldaşıyordu cilalı yapraklar, ince esintide. Güneş vurmuştu. Yapraklar adeta elmas serpintili.” (İleri, 2007: 23)

örneğinde de "yapraklar" sözcüğü, başka bir göstergeyle verilmek yerine sürekli tam tekrar yoluyla yüzey yapıda tutulmuştur.

“Ama İrene’ye vaktiyle söylemişlerdi. İrene’ye, vaktiyle, hiçbir şeyin düzelmeyeceğini, onmayacağını, dünyanın ve gökyüzünün sonsuz karanlığını, İsa'nın hiçliğini, marangoz Yusuftan gebe kalmış Meryem'in yalancllı̆̆ını, meleklerin olmadığını. Olmadığını!

Olmadığını. İrene kendine söylemişti.” (İleri, 2007: 74)

Yukarıdaki örnekte de “İrene’ye”, “vaktiyle” "olmadiğını” sözcükleri, aynen tekrarlanmaktadır.

\section{Bilinç karışıklığı, göstergelerin de karışık biçimde kullanılmasına yol açmıştır:}

İrene, kimi zaman kendini dışarıdan seyreden biri gibidir. Sürgündeki İrene, özellikle İmparatoriçe İrene'yi anlattığı zamanlarda kendini soyutlama yoluna gider. Bu da anlatıcıyı veren göstergelerde değişmeler olmasına ve cümleler arasındaki bağların bağdaşıklık açısından gevşemesine yol açar.

“Kızkardeşlerimin akıbeti. Merak etmedi İrene. Hangi alınyazısında kavruldular.” (İleri, 2007: 152)

söyleminde İrene önce, birinci tekil kişi olarak okurun karşısındadır: "Benim kızkardeşlerim.” Bir sonraki cümledeyse kendini uzaktan seyreden biri gibidir ve üçüncü tekil kişi olarak görülür: "Merak etmedi İrene."

Aşağıda da önce birinci tekil kişidir: "Ben ... koşmuş ve ben ... sığınmıştım." Sonra kendinden yine üçüncü tekil kişi gibi söz eder: “...sarılmış İrene, ağlamış İrene.”

"Perdelerim uçuşuyordu, Yeni Saray'da, tarihçilerin kimliğini çözemediği bir adamın sarayının yıkıntıları üstüne inşa ettirdiğim, perdelerime koşmuş ve sığınmıştım, sarılmış, ağlamış İrene.” (İleri, 2007: 174) 

106-122)

Başka bir örnekte, İrene önce kendine "sen” diye hitap eder: "Sen duraksadın İrene. Sen yanılyyorsun." Sonra "Atina'daki kız" söylemiyle üçüncü tekil kişi konumuna geçer: "Atina'daki kız, ... 'basileus' için dilek tutardı.” Ardından birinci tekil kişiye döner: "Ben yine yanıldım.” Söylemin sonunda yeniden “Atina’daki kız"a gönderme yapar ve bir kez daha üçüncü tekil kişi olarak görülür: "O (Atina'daki kzz), Basileus'tan nefret ederdi. O (Atina'daki kzz), insanhı̆ın iyiliği için yakarmışt..”

“Duraksadın İrene. Yanılıyorsun. Atina'daki kız, şehveti dinmemiş... şehveti gelinlik kızlara acıkmış kayınbabası için değil; 'basileus' için dilek tutardı.

Yine yanıldım: Basileus’tan nefret ederdi. İnsanlığın iyiliği için yakarmıştı, yoksullar kurtulsun diye.” (İleri, 2007: 110)

Cümleleri bir araya getiren metin içi bağlardan biri de zaman uyumudur (Çakır, 2014: 19). Buna göre cümleler, dil bilgisel zaman açısından denklik göstermelidir. Ancak Hepsi Alev'de bazen zaman ekleri de ardışık cümlelerde farklılaşır. Örneğin aşağıdaki söylemde önce -\{mIştI\} ekiyle geçmiş zaman anlatımı görülür; burada anlatı zamanı odaklı bir anlatım söz konusudur. Sonraki cümlelerdeyse aynı olayın devamı $-\{$ AcAK\} ekiyle olay zamanı odak alınarak sunulur:

"Aklı iyice karışmıştı. Handiyse yanımdan kaçıp gidecek. Ona sorular soracağım, Nikeforos'un adamlarının aklına gelmemiş.” (İleri, 2007: 31)

\section{Bunların dışında dil bilgisi kuralları açısından aykırılık göstermeyen bazı kullanımların, bilinç akışı tekniğine bağlı olarak tercih edildiği dikkati çeker:}

\section{Kahraman, sık sık ara cümle ve ara sözlerden yararlanmıştır:}

İrene, bilinç düzleminde aklına gelenleri, aşağıda görüldüğü üzere, çoğu zaman ara söz ya da ara cümle biçiminde verir:

\footnotetext{
"Konstantinos'la... büyükbabasının adaşı oğlumla. İmparator artık ölmüştü. İçeriye girdiğimizde. Erguvan renkli yastıklara başı gömülü.” (İleri, 2007: 73)

“Gülümsemiyordu Meryem. İsa'nın... bağrından çıkanın başına gelecekleri bildiği için, gözleri hüzün doluydu. Bilmem o da İsa gibi insanlığı... oğlunu çarmıha gerenleri bağışlar mı.” (İleri, 2007: 47)
}

Olaylar aktarılırken bilinçteki karışıklıktan dolayı söylenmesi unutulanlar, ara söz ya da ara cümle biçiminde araya girmekte, bu da kesik cümle görünümünde yapıların ortaya çıkmasına neden olmaktadır. Aşağıdaki söylemde böyle bir durum söz konusudur.

“Artık Lesbos’a götürüleceğimi söyleyen alçaklara...

... Açıça tebliğ ettiler.

Alçaklara, ‘Bana şarap verin!' dedim, ‘sevdiğim kırmızı şaraptan.’” (İleri, 2007: 13)

örneğinde "Artık Lesbos'a götürüleceğimi söyleyen alçaklara 'Bana şarap verin!' dedim, 'sevdiğim kırmızı şaraptan.” cümlesi aralanarak "Açıkça tebliğ ettiler." ara cümlesi araya sokulmuştur. "Artık Lesbos’a götürüleceğimi söyleyen alçaklara...” cümlesi, kesik cümle gibidir. Ancak dikkat edilirse üç nokta işaretinin, cümlenin kesildiğini değil araya yardımcı unsur, ara cümle alındığını işaret ettiği görülür. Ara cümleden sonra cümle, kesildiği yerden devam etmektedir.

Aşağıdaki örnekte de aynı durum vardır. Ara cümleler, aynı yöntemle araya girmiştir:

“Konstantinos’a gelişimden... getirilişimden... 
... Hep sürgün gibi! Konstantinopolis'e, Prinkopo'ya getirilişim gibi 'getirildiğimi' ilk kez ayırt ediyorum.

Konstantinopolis'e getirilisimden epey önce, basileus, Hieria Sarayı'nda kendinden menkul bir Ruhanî Meclis toplamış." (İleri, 2007: 86)

Romanda üç nokta işaretinin, slklıkla ara söz ve ara cümlelerin belirtilmesinde kullanıldığı dikkati çeker:

"Duraksadın İrene. Yanılıyorsun. Atina'daki kız, şehveti dinmemiş... șehveti gelinlik kızlara acıkmıș kayınbabası için değil; 'basileus' için dilek tutardı." (İleri, 2007: 110)

“İmparatoru aldattım, kocamı... sonraki imparatoru da. Aldattım.” (ileri, 2007: 40)

Bu açıklayıcı ifadelere bazen yanlış ya da eksik sözleri doğrulamak üzere başvurulduğu da görülür:

"Mutsuzluğa... mutsuzluğun iyileşmesine rüzgârların yarayıp yaramayacağını soran genç asker, her nedense, bu duygusallığa karışıyor: Onun şimdi kaç yaşında olduğunu hesaplamaya çalışıyorum. Büyük olasilıkla öldü. Ruhu...

... Leon yerine onu sevmeye çalışsaydım... ” (İleri, 2007: 41)

"Yüce Allahım, ölmediğim gibi... ölemediğim yetmiyormuş gibi, Kör Şehitler Kilisesi'nin bahçesinden, çiçeği durmuş nar ağacından, bilge Kalinikos'tan, bundan böyle ruhumun acısına merhem olamayacak Homeros'tan, şiirden, geçmiş zamanın uygarlığından kurtulamıyorum.” (İleri, 2007: 150)

\section{Devrik yapılar da oldukça sık kullanılmıştır:}

Romanda hem cümle hem de sözcük öbeği bünyesinde devriklikler oldukça fazladır. Bu da bilincin karışıklığının bir göstergesidir. İrene, aklına gelenleri rastgele dile getirdiği için ögelerin sıralanışında devriklikler ortaya çıkmıştır.

"Yoksullar da kiliseyi unutacak, yarın." (İleri, 2007: 150) örneğinde cümle, devrik kurgulanmış; zaman zarf tümleci görevindeki "yarı" ögesi, yüklemden (unutacak) sonraya bırakılarak virgülle de ayrılmıştır. Burada virgül işaretinin, yukarıda örneklenen nokta işaretinde olduğu gibi, düşüncelerdeki duraklamanın yazı dilindeki bir başka göstergesi olduğu düşünülmektedir.

"Sonbahardr. Lodostu; rüzgâr." (İleri, 2007: 161) örneğinde de benzer bir kullanım söz konusudur. Burada ikinci cümlede "lodostu" yükleminden sonraya bırakılan öge (rüzgâr) öznedir. Duraklamaysa noktalı virgül ile gösterilmiştir.

Kimi zaman da sözcük öbekleri devrik kurgulanır. Aşağıdaki örnekte "sonbaharın yağmuru" biçiminde tamlayan + tamlanan biçiminde olması gereken belirtili ad tamlaması yapısındaki sözcük öbeği, unsurların yerleri değiştirilerek kullanılmıştır. Dolayısıyla sözcük öbeği düzleminde bir devriklik oluşmuştur:

"Evet, kesenkes eylül sonu. Yağmuru sonbaharın. İlk sarı yaprak. Yağmur gözlerimden de süzülüyor. Mil çektirtilmeyen zümrüt gözlerimden, kan çanağı." (İleri, 2007: 184)

\section{Gizli bir diyalog hissi uyandran söylemler de yaygmder:}

İrene, kendisini okurla karşıya karşıya bulmuş gibidir. Âdeta ona içini dökmekte, onunla dertleşmektedir. Bu da aklından geçenlere yansımış ve okurla diyalog kuruyor hissi yaratan kullanımların ortaya çıkmasını sağlamıştır. 
Kimi zaman okurun kendisi hakkındaki düşüncelerini, yorumlarını bilir gibi davranır.

"Aklın yordamına güvenirsek, ölüm hazırlıkları içinde olmalıydım. Getirip bıraktıkları çile köşesinde. Bizans'ın geleneğini bilmez değilim. Günahlarımı, suçlarımı sayıp dökmeliydim.” (İleri, 2007: 18)

Yukarıdaki örnekte sanki karşısındaki okurun, kendisine "Bizans'nn geleneğini bilmiyorsun.” dediğini varsaymakta ve buna itiraz edercesine $-\{\mathrm{mAz}$ değil $\}$ yapısını kullanarak "Bizans’in geleneğini bilmez değilim.” demektedir. Bu da onun bir savunma durumu içinde olduğunu gösterir.

Bazen de zihin karışıklığından dolayı ne söylediğini hatırlayamaz, okura soru sorar:

"Söylemiş miydim, sanat iyileştirir, yaraları sarar. Bazan. Yoksulluktan kurtulmuşsanız." (İleri, 2007: 52)

\section{Yorum ve çıkarm cümleleri de romanda önemli bir yer tutar:}

Bilinç akışı tekniğinde, anlatmaktan çok göstermek amaçlanır (Kale, 2015: 92). Ancak okura gösterilmek istenenler, yaşanan olaylar değil bu olayların kahramanların iç dünyalarındaki karşılığıdır. İleri de roman kişilerinin gördüklerinin, yaşadıklarının bilinçteki yansımalarını bilinç akışıla göstermeyi tercih eder. Mengi, yazarın bu tekniği kullanarak okura, sözü edilen olayların insan psikolojisindeki karşllı̆̆ını, yarattığı çağrışımları, kahramanın bunlardan nasıl etkilendiğini ve neler hissettiğini izleme olanağı sağladığını dile getirir (Mengi, 2012: 136).

Hepsi Alev'de de İrene'nin bilinç düzleminde olaylarla birlikte onun kişiler, olaylar, durumlar hakkındaki yorumları, bilinçaltındaki düşünceleri, duyguları da gösterilmektedir. Bu nedenle yorum ve çıkarım cümleleri, İrene'nin kendisi dışındaki dünyaya nasıl baktığını, onun nasıl hissettiğini göstermesi amacıyla sıklıkla kullanılmıştır.

Örneğin aşağıdaki söylemde İrene, Demo için “Çehresi güzel ve aptal.” yorumunda bulunur. Olayları anlatırken araya öznel değerlendirmesini sıkıştırır. $\mathrm{Bu}$, onun bilinçaltındaki düşüncelerinin dışa vurumudur:

"Susup kaldı Demo, şarabı sunarken. Altın kupada nektar karıştırmayarak. Çehresi güzel ve aptal." (İleri, 2007: 14)

Aşağıdaki örnekteyse bir çıkarım yapar. Söz ettiği kişilerin şarabın miktarını artırmalarının sebebi, ona göre kendisinin ömrünü kısaltmak istemeleridir:

"Yöntem değişti: Şarabın miktarını artırdılar. Ömrü kısaltmanın bir yolunu yordamını da böyle gördüler herhalde." (İleri, 2007: 132)

\section{Sonuç}

Bu çalışmada, Selim İleri’nin Hepsi Alev romanında bilinç akışı tekniğinden kaynaklanan kullanımlar dil bilgisi kuralları çerçevesinde incelenmiş; eserin bilinç akışı diliyle ilgili pek çok veri sunduğu görülmüştür. Değerlendirilen örneklerin bir kısmının dil bilgisi kurallarına çeşitli bakımlardan aykırılık gösterdiği, kurallara uygun birtakım kullanımlarınsa tekniğe bağlı olarak tercih edildiği sonucuna ulaşılmıştır.

Eserde bağdaşıklık, tutarlılık, en az çaba gibi ilkelere ve dil bilgisi kurallarına uymayan çeşitli kullanımlar saptanmıştır. Bunlar, şöyle özetlenebilir: Bilinç akışı, bir sayıklama hâlidir; romanda bunun 
verilebilmesi için cümleler arasında konu bütünlüğünün bozulduğu görülür. Sürekli geri gidişler, ana dönüşler, birbirinden anlamca kopuk cümlelerin art arda sıralanması, anlatımda dağınıklığa sebep olmuş; tutarlılık ilkesi göz ardı edilmiştir. Romanda cümlelerin dağınık olması, çoğu zaman çağrışımlardan kaynaklanır. Çok sık kullanılan yüklemsiz kesik cümleler de anlamın kapalı kalmasına, tutarlılık ilkesinden uzaklaşmaya neden olmuştur. Çoğu zaman gönderimlerin uzak oluşu, göstergeler arasına farklı bilgilerin girişi de metni anlaşılmaz kılan unsurlardan biridir. Yine alışılmamış bağdaştırmalar ve bazı karşıtlıklarla da sıra dışı kullanımlar yaratılmıştır. Romanda, dilde en az çaba ilkesine aykırı söylemler de oldukça fazladır. Örneğin kahramanın, aklına gelenleri kesintili biçimde sunmasından dolayı ortaya çıan yüklemli kesik cümleler, gereksiz eksiltilere sebep olarak cümle sayısının artmasına yol açmıştır. Yüzey yapıdaki gereksiz tekrarlar da dilde tasarrufa gidilmediğinin göstergesidir. Bunlar, bağdaşıklık açısından da sorunludur. Dil birimlerinin sıralanışında da bağdaşıklık ilkesine aykırı durumlar görülebilmektedir.

Romanda dil bilgisi kuralları açısından aykırılık göstermeyen bazı kullanımların, bilinç akışı tekniğine bağlı olarak tercih edildiği dikkati çeker. Bilgi vermek ya da düzeltme yapmak için ara cümle ve ara sözlere oldukça fazla yer verilmiştir. Bilincin karışıklığının bir göstergesi olarak hem cümle hem de sözcük öbeği bünyesinde devriklikler oldukça fazladır. Gizli bir diyalog hissi uyandıran dil birimleri de yaygındır. Öznel değerlendirmeleri içeren yorum ve çıkarım cümleleri, bilinçaltındaki düşüncelerin yansıtılması için çok sık kullanılmıştır. Ayrıca romanda bilinç akışını verebilmek için noktalama işaretlerinin gücünden de yararlanılmıştır.

Elde edilen sonuçlar, bilinç düzleminde ve bilinçaltında var olanların dilde özel kullanımlarla kodlandığını, bilinç akışına özgü bir işaretleme biçimi olduğunu ortaya koymaktadır. Ancak bu romanda görülmeyen, diğer eserlerde kullanılmış başka özellikler de olabilir. Bu nedenle karşıllaştırmalı çalışmalar yapılması gerektiği, böylece bilinç akışı dilinin bütüncül biçimde görülebileceği düşünülmektedir.

\section{Kaynakça}

Aydın, H. (2011). "Dilde En Az Çaba İlkesi” Üzerine. IJSES Uluslararası Sosyal ve Ekonomik Bilimler Dergisi, 1 (1), 1-6.

Çakır, A. (2014). Söylem Analizi-Ne Demek İstiyorsun?. Konya: Palet.

Çetin, N. (2013). Roman Çözümleme Yöntemi. Ankara: Öncü Kitap.

Çetişli, İ. (2004). Metin Tahlillerine Giriş / 2 - Hikâye-Roman-Tiyatro. Ankara: Akçă̆.

Çokay Nebioğlu, R. (2019). Virginia Woolftan Sevgi Soysal'a Edebiyatta Modernizm: Dalgalar İle Yürümek Romanları Üzerine Karşılaştırmalı Bir İnceleme. Turkish Studies, 14 (3), 1308-2140.

Dizdaroğlu, H. (1976). Tümcebilgisi. Ankara: TDK.

Elmas, N. (2011). Mustafa Kutlu’nun “Bu Böyledir” Adlı Hikâye Kitabında Bilinç Akışı ve İç Monolog Tekniği. Karadeniz Araştırmaları, 29, 133-145.

Hengirmen, M. (2009). Dilbilgisi ve Dilbilim Terimleri Sözlüğü. Ankara: Engin.

İleri, S. (1977). Romanı Yazarken. Türk Dili, 304 / 34, 245-252.

İleri, S. (2007). Hepsi Alev. İstanbul: Doğan.

Kale, Ö. (2015). Edebiyatta Bilinç Akışı Tekniğine Başvurulma Sebepleri Üzerine Bazı Dikkatler. NWSAHumanities, 10(2), 88-93.

Karabulut, M. (2012). Yusuf Atılgan'ın “Aylak Adam” Romanında Anlatım Teknikleri. Turkish Studies, $7(1), 1375-1387$. 
Karahancı, İ. (2014). Şarkı Sözlerinden Hareketle Dilde Bağdaşıklık Sorunları. Turkish Studies, 9 (9), 699-712.

Karatekin, T. (2019). Fikrimin İnce Gülü Romanında Bilinç Akışı Tekniği. Avrasya Sosyal ve Ekonomi Araştırmaları Dergisi, 6 (1), 215-230.

Keklik, M. (2013). Dilbilimsel Açıdan Şiir Dili ve Bu Bağlamda Baki'nin Gazellerinde Alışılmamış Bağdaştırmalar Duygu Değeri ve Uzak Çağrışımlar. Turkish Studies, 8 (9), 1801-1818.

Maktal Canko, D. Y. (2019). Türk Edebiyatında Bizans İmparatoriçeleri ve Selim İleri’nin "Hepsi Alev" Romanı. RumeliDE Dil ve Edebiyat Araştırmaları Dergisi, 16, 308-318.

Mengi, N. (2012). Selim İleri’nin Romancılığı ve Türk Romancılığındaki Yeri. Folklor/Edebiyat, 18 /71, 127-141.

Moran, B. (2002). Türk Romanına Eleştirel Bir Bakış 1. İstanbul: İletişim.

Odacı, S. (2009). Ulysses ve Tutunamayanlar'da Bilinç Akışı Tekniği. Turkish Studies, 4 (1), 605-684.

Onursal, İ. (2003). Türkçe Metinlerde Bağdaşıklık ve Tutarlılık. Yayına Hazırlayanlar: Prof. Dr. Ayşe Kıran, Doç. Dr. Ece Korkut, Dr. Suna Ağıldere, Günümüz Dilbilim Çalışmaları (ss.121-132). İstanbul: Multilingual Yayınları, Dilbilim Dizisi.

Öğüt, H. (2007). Yazar ile Kahramanı: Selim İleri ve İrene. Mesele Kitap Dergisi, 2, 33-36.

Sazyek, H. (2015). Roman Terimleri Sözlüğü - Roman Sanatından Yüz Terim. Ankara: Hece.

Tekin, M. (2001). Roman Sanatı -Romanın Unsurları 1. İstanbul: Ötüken Neşriyat.

Üstünova, K. (2014). Türkiye Türkçesinde Yapı Kavramı ve Söz Dizimi İncelemeleri. Bursa: Sentez. 